\title{
May E-Governance Create Digital Divide?
}

\section{Rowshon Ara Romke}

Lecturer, Department of Applied Sociology, ASA University Bangladesh

\begin{abstract}
Developing country (DC) governments have been using information and Communication technologies (ICTs) supporting and transforming the external Workings of governance by processing and communicating data. EGovernance should be seen to encompass all ICTs, but the key innovation is computer networks. Bangladesh has failed to progress towards achieving its target as envisaged in its information Technology (IT) policy documentation. Besides, the unequal access to computers and other digital technologies in the developing world from the developed world creates digital divide. Closing the technology gap would lift people out of poverty, while creating a large business opportunity for the high technology industry (World Resources Institute, 2000). My aim in this paper is to present an outline of EGovernance which create digital divide in Bangladesh. This type of research is rare and it would help the society and the country to understand the problem of digital divide and the progress of E-Governance. The paper concludes some problems designed to stimulate farther thoughts and advanced research.
\end{abstract}

Key words: E-Governance, Digital Divide, Digitally Wealthy, Digitally Poor JEL Classification Code: G39

\section{INTRODUCTION}

$\mathrm{A}$ vailable ICTs infrastructures with government's willingness to implement e-governance have already brought success in e-government initiatives. Some developing countries are trying to improve their governance structure. Therefore, they are facing some barriers. For example, lack of ICTs resources and infrastructure such as high speed broadband network connection, unequal access of technology (resulting into 'digital divide'), low literacy rate, corruption, lack of government policy initiatives. A strong political will and commitment are required to combat these barriers and achieving success. The emergence of Information and Communication Technology (ICT) has provided faster and better communication, efficient storage, retrieval and processing of data and exchange and utilization of Information to its users (Planning Commission, 2001). Egovernance or 'electronic governance' is basically the application of Information and Communication Technology to the process of government functioning in order to bring about 'Simple, Moral, Accountable, Responsive and transparent (SMART) governance (Rahman \& Naz, 2006).

From the above discussion it can be seen that e-governance or i-governance is basically ICT based and digital divide is creating for imbalance penetration of ICTs. Both the term (egovernance and digital divide) is relevant to ICTs. Here egovernance is cause and digital divide is effect. In this study, there are two variables: dependent and independent variable. Overall, e-governance is the ICT enabled route to achieving good governance. Same time, to ensure this egovernance or good governance-digital divide creates a major problem in the developing countries. Many researchers show that digital divide creates poverty, corruption, etc.

\section{ObJectives OF THE Study}

The main objectives of the study are as follows:

- To analyze the reasons which are created digital divide by e-governance.

- To recommend some suggestions in order to overcome the barriers of e-governance.

\section{CONCEPTUAL FramEWORK OF E-gOVERNANCE AND E-GOVERNMENT}

E-government and e-governance can be defined as two very distinct terms. E-governance is a broader topic whereas egovernment is actually a narrower discipline dealing with the development of online services to the citizen.

\section{E-Governance}

Some widely used definitions are listed below:

The Council of Europe has taken e-governance to mean:

"The use of electronic technologies in three areas of public action:

- relations between the public authorities and civil society

- functioning of the public authorities at all stages of the democratic process (electronic democracy)

- the provision of public services (electronic public services)" (http://www.coe.int).

From this meaning it is said that, with a view to encourage better interaction between government and citizens, promote democracy and provide public services electronic technologies are using.

The US E-Government Act of 2002 defines "electronic Government" to mean- 
"The use by the Government of web-based Internet applications and other information technologies, combined with processes that implement these technologies, to-

(A) Enhance the access to and delivery of Government information and services to the public, other agencies, and other Government entities; or

(B) Bring about improvements in Government operations that may include effectiveness, efficiency, service quality, or transformation" (E-government Act 2002).

This definition reflects the strategy of the US Government regarding the use of ICT in improving Government operations on the one hand and enhancing the access and delivery of information and services to citizens and government entities on the other.

There are three main domains of e-governance,

- Improving government processes: e-Administration

- Connecting citizens: $e$-Citizens and e-Services

- Building interactions with and within civil society: $e$ Society (Bhatnagar, 2004).

Three domains of e-governance should be recognized as overlapping, as shown in the figure 1.

Figure 1: Overlapping domains of e-governance

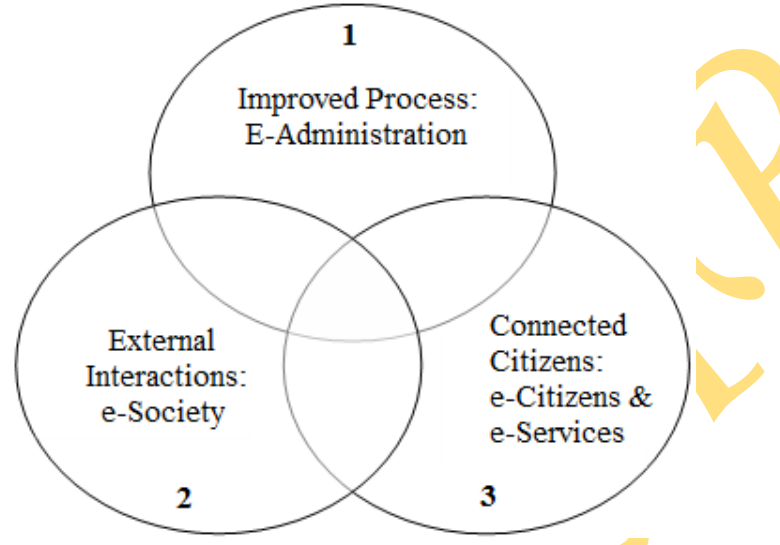

These overlapping domains of e-governance focus on the problems that government is too costly, too inefficient and too ineffective; too self-serving and too inconvenient; and too insular.

Figure 2: Focal Domains for e-governance Initiatives External Interactions

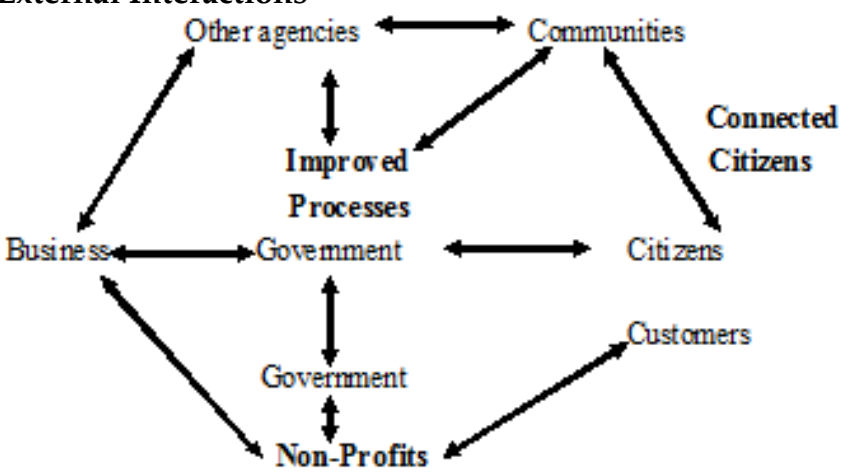

Mentioned above figure indicates the connectivity of the focal domains of e-governance.
Dr. APJ Abdul Kalam, former President of India, has visualized e-Governance in the Indian context to mean:

"A transparent smart e-Governance with seamless access, secure and authentic flow of information crossing the interdepartmental barrier and providing a fair and unbiased service to the citizen" (International Conference).

\section{E-Government}

E-government is a generic term for web-based services from agencies of local, state and federal governments. In e-government, the government uses information technology and particularly the Internet to support government operations engage citizens, and provide government services. The interaction may be in the form of obtaining information, filings, or making payment and a host of other activities via the World Wide Web.

Definition of the Working Group on E-government in the Developing World:"E-Government is the use of information and communication technologies (ICTs) to promote more efficient and effective government, facilitate more accessible government services, allow greater public access to information, and make government more accountable to citizens.EGovernment might involve delivering services via the internet, telephone, community centers (self-service or facilitated by others), wireless devices or other communications systems." (www.pacificcouncil.org).

In short e-government and e-governance is:

\begin{tabular}{|c|c|}
\multicolumn{2}{c|}{ E-Governance vs. E-Government } \\
\hline E-Government & E-Governance \\
\hline Electronic service delivery & Electronic consultation \\
\hline Electronic workflow & Electronic controllership \\
\hline Electronic voting & Electronic engagement \\
\hline Electronic productivity & Networked societal guidance \\
\hline
\end{tabular}

\section{ANALYSIS OF the CONCEPT 'Digital DiviDE'}

The term Digital divide is used as digital poverty, information poverty, and digital gap. Digital poverty is defined as a lack of ICT with regards to access and use of the information and communications allowed by the technology. Mark Warschauer (2003) argues that the term should not be used at all, instead it should be replaced by 'social inclusion' which sounds more positive and does not presuppose that there is a separation between those who are 'inside' or 'outside' or on 'this side' or 'that side' of the divide.

Digital divide is a cause of social inequality, the access and usage of information technology is good. Divide between the rich and the poor is created by the fact that the former have the money, whereas the latter do not, and this becomes a problem because money or wealth seems to be universally desired. On the other hand, having access to information technology means that one gains a significant advantage over those who don't, because having access means one is able to acquire benefits such as information, access to up-to-date data, knowledge, and so on, which would not have been possible if she/he did not have the access. The 1999 United Nations Human 
Development Report, for example, observed the following about Internet use worldwide:

The typical Internet user worldwide is male, under 35 years old, with a college education and high income, urban-based and English-speaking - a member of a very elite minority worldwide. The network society is creating parallel communications systems: one for those with income, education and literally connections, giving plentiful information at low cost and high speed; the other for those without connections, blocked by high barriers of time, cost and uncertainty and dependent on outdated information. With people in these two systems living and competing side by side, the advantages of connection are overpowering. The voices and concerns of people already living in human poverty, less income and education and access to public institutions are being increasingly marginalized. (UN 1999, p. 63).

This observation gets to the heart of what social scientists call the "digital divide," or the gap between those with access to the Internet and those without. In the United States, for example, the National Telecommunications and Information Administration (NTIA) has tracked Internet access and developed policy recommendations to close gaps in such access (NTIA 1995, 1998, 1999, 2000, 2002). Among the "Digital divides" noted by the NTIA is a divide between urban and rural areas, between whites and non-whites, between the young and old, and between the economically active inactive (DiMaggio et al. 2001). Perhaps an individual has Internet access at home, but their dial-up speed is slow and hence their Internet usage is limited. Perhaps an individual has high-speed Internet, but little knowledge of search engines and how to "surf" the Internet, narrowing the scope of what they can get out of being online. The research and policy agenda must be broad enough to tackle these differences and the inequalities they produce (Witte \& Mannon, 2010). It shows how Internet inequalities are manifesting among the online population and the overall population. From the above concept of digital divide of different experts it can be said that, digital divide is a kind of social stratification. There are two groups living side by side: one group is connected to the modern digital technology and other group is disconnected.

\section{Three Stages of Digital Divide}

The digital divide is manifested in the fact that some people can't afford to buy a computer. We should recognize that for truly poor developing countries, computers will remain out of the average citizen's reach for 20 years or more. In areas like North America, Europe, Australia, and Asia's advanced countries, computer cost is no longer an issue.

Stage 2: Usability Divide

Lower literacy is the Web's biggest accessibility problem, but nobody cares about this massive user group. Senior citizens face the second-biggest accessibility problem. Even though seniors are the main remaining source of growth in Internet use, companies are still endlessly fascinated by young users and ignore older, richer users who would be more active in economics and thus they can easily get or purchase digital technology. On the other hand the poor are disadvantaged group.

Not everybody would make full use of the opportunities that such technology affords. Participation inequality is one exponent of the empowerment divide that has held constant throughout all the years of Internet growth: in social networks and community systems, about $90 \%$ of users don't contribute, 9\% contribute sporadically, and a tiny minority of $1 \%$ accounts for most contributions.

\section{LEVELS OF DigITAL DIVIDE}

\section{Figure 3: Levels of digital divide}

Functionality
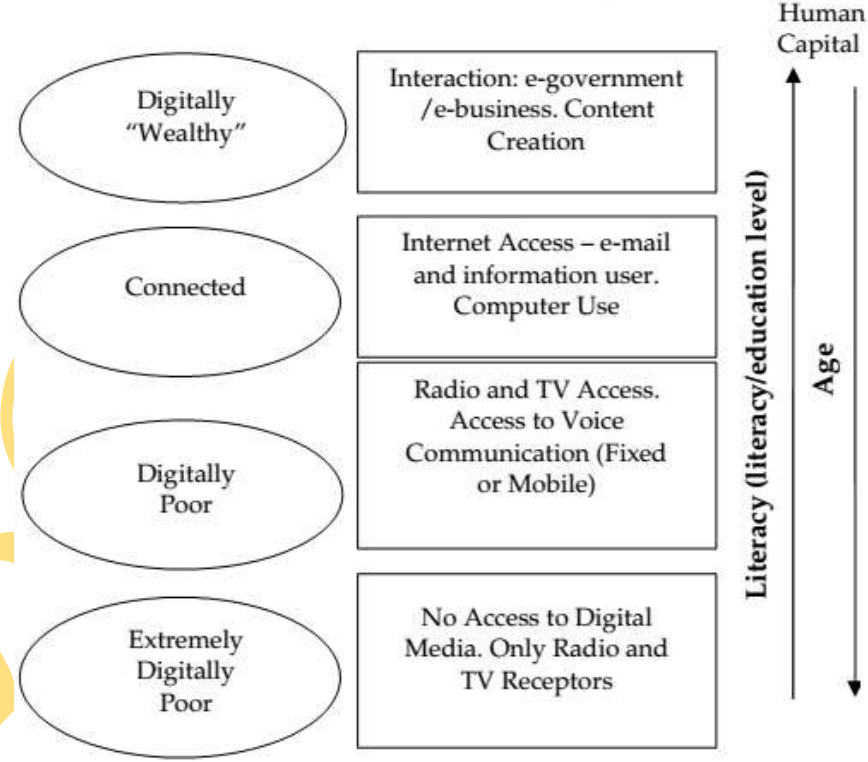

From the figure I can summarize that, it is the few who have access to ICTs, to digital information and knowledge, and to the benefits of reform in governance. We can thus talk of an 'e-governance divide' that is increasingly separating developed and developing countries, and elites and ordinary citizens within developing countries.

\section{Global Scenario of Digital Divide}

Arrival of internet is a positive impact on various parts of life such as business, personal and governmental level. Information and Communication Technologies (ICT) have played a major role in late $20^{\text {th }}$ century. As it is obvious that the largest part of the world remains unconnected. While Asia has almost $61 \%$ population of world and Africa $14 \%$, their share of internet penetration is very low.

Internet penetration across geographies

\begin{tabular}{|l|l|}
\hline Continent & Internet penetration \% \\
\hline Asia & $10.4 \%$ \\
\hline Middle East & $9.6 \%$ \\
\hline North America & $68.6 \%$ \\
\hline South America & $14.7 \%$ \\
\hline Europe & $36.4 \%$ \\
\hline Africa & $2.6 \%$ \\
\hline Oceania & $52.6 \%$ \\
\hline
\end{tabular}

Source: www.internetworldstats.com 
World population distribution

\begin{tabular}{|l|l|}
\hline Continent & Population as \% of world population \\
\hline Asia & $60.67 \%$ \\
\hline Africa & $13.82 \%$ \\
\hline Europe & $11.31 \%$ \\
\hline North America & $7.94 \%$ \\
\hline South America & $5.76 \%$ \\
\hline Oceania & $0.51 \%$ \\
\hline
\end{tabular}

Source: U.S. Census Bureau, International Programs Centre, 2009

Digital divide is becoming evident (Devraj, 2000) in developing countries. Due to poor purchasing power even the same or lowered cost remains a cause for digital divide. Slow speed of internet penetration and disappointing growth-rate of broadband adoption is also an important aspect of the whole scenario.

\section{E-governance and Digital Divide in Bangladesh}

Bangladesh has not kept up with ICT Developments worldwide, even compared to other nations in a similar economic position, and the overall ICT infrastructure is poor. Public sector ICT infrastructure and usage is quite merging, with inadequate hardware resources and a lack of information technology (IT) expertise in most government offices. Many of the existing PCs are outdated and insufficient for every 100 employees there are 30 computers at the ministry level and 8 computers at the division level. On an average at the ministry and division level, only 48 percent of PCs are connected to the internet.

The World Economic Forum (WEF) prepared "Global Information Technology Report (GITR) 2009-2010" reviewed Bangladesh's placement on three key ICT Indicators: 1. Environment (infrastructure, market and political), 2. Readiness and 3. Usage. These indicators gauge preparedness to leverage ICT advancement for increased competitiveness and development in general, and in comparison to other nations. Bangladesh ranks 118 out of 133 countries. The country's overall low ranking highlights the urgent need for improvements in areas such as 1. Improving the regulatory framework, 2. Developing human resource capacity, 3. Providing greater access and increasing usage of ICT by citizens and 4 . Investing in ICT infrastructure.

\section{Bangladesh's ICT status}

\begin{tabular}{|c|c|c|c|c|c|}
\hline Criteria & Bangladesh & India & Srilanka & Pakistan & Nepal \\
\hline Overall rank & 118 & 43 & 72 & 87 & 124 \\
\hline
\end{tabular}

Overall, Bangladesh ranks 118 among 133 countries but fares worse than most of its South Asian counterparts in the ICT sector. Individual usage takes stock of ICT penetration and diffusion at the individual level, whereas business and government assesses ICT penetration in business and government respectively. Bangladesh fares worst in South Asia at usage by all the different stakeholders, highlighting this as the area that requires significant government focus. It ranks 130th (out of 133) in the presence of ICT tools in government agencies, showing extremely poor penetration and diffusion of ICT in government agencies. India ranks highest at 64 , followed by Srilanka at 82 and Pakistan at 93.

\begin{tabular}{|c|c|c|c|c|c|}
\hline Criteria & Bangladesh & India & Sri Lanka & Pakistan & Nepal \\
\hline Usage & 126 & 64 & 82 & 94 & 129 \\
\hline Citizens & 127 & 109 & 101 & 102 & 125 \\
\hline Business & 126 & 26 & 61 & 80 & 121 \\
\hline Government & 115 & 48 & 59 & 91 & 124 \\
\hline
\end{tabular}

Source: WEF-INSEAD GITR (2009-2010).

\section{Info Ladies from Pallitathya Kendras:}

Info Ladies are a group of young women on bicycles equipped with net books, phones, and medical equipment who deliver ICT access to rural people. They are the bearers of information in an information-scare society. Their net books come loaded with village-relevant content that is translated to Bengali. "Form agriculture to health, sanitation and disaster management, the content follows simple text, pictures and engaging multimedia animations to include all users, many of whom are illiterate." (Kumar 2009)They also carry items like blood pressure monitors and pregnancy kits in their bags, and are able to send pictures of simple diseases and skin conditions to Dhaka for diagnosis. Because rural women suffer most from a lack of knowledge about medical, legal and social issues, a female information provider bridges the divide, making them more likely to be open. While in the past the young, modern Info Ladies were regarded as something of a 'scandal', they have now become the source of information for individuals looking requiring disparate information such as their blood pressure reading or ways to increase crop yield (The state of Governance of BD 2009).

\section{Reasons for Creating Digital Divide}

From the above discussion I can find out some points:

1. Technological problems: Inadequacy of ICT infrastructure is a common problem in most government offices of Bangladesh. This situation is marked the absence of technical infrastructure planning and sub-optimal utilization of whatever infrastructure is available. And this aspect is increasing the digital divide between developed countries and LDC, between urban and remote areas in a country. Integration problem is one of the reasons for this gap.

2. Problem of Human Resource management: Due to lack of utilized the skill, knowledge of the experts; many e-government implementation projects suffer from lack of skilled human capital. Only ICT skill courses available for the civil servants are not enough to bridge the gap. Absence of incentive for acquiring ICT skill is also considered as one of the reason for lacking of ICT skilled human resources in the government.

3. Financial problem: Absence of pro-private sector policies impedes this other potential source of 
investment. Indeed the lack of managerial acumen and technical know-how to analyze the cost-benefit scenario and return on investments to assess financial sustainability of a project is hurting the country's egovernance aspirations. It is also an important reason why the private sector remained as a skeptic bystander rather than an active partner in egovernance (Morshed, 2007).

4. Social disparity: In Bangladesh, a country where 'disparities' between haves and have-nots are ever increasing, introducing ICT in the governance mechanism faces the challenge of ensuring equitable access to e-governance services by all strata of the society. The other social disparity challenges are lack of literacy and a weak basic education standard; standardization of Bangla for official use; and the 'Brain Drain' of ICT skilled human resources from the government.

5. Administrative problem: It is mostly due to this lack of awareness that e-governance systems lack buy-in from the senior management of government organizations. Such lacking of acceptability often means lack of sustainability of the system and even failure to implement such a system.

6. E-service delivery problem: Digital divide is considered one of the main barriers to implementing e-services; some people do not have means to access the e-services and some others do not know how to use the technology (or the e-service). According to Helbig. (2009), "we suggest e-government and the digital divide should be seen as complementary social phenomena (i.e., demand and supply). Moreover, a serious e-government digital divide is that services mostly used by social elites."

7. Slow Paced IT and the Digital Divide: Even with the slow paced IT revolution in Bangladesh, around 50\% or more of our villages are still without telephones. $75 \%$ or more of our population resides in the rural areas and do not have adequate exposure to technology. A vast majority lives below the poverty line and $35 \%$ or more are illiterate. Like any other developing country a vast majority of Bangladesh population will be vulnerable to the risk of getting marginalized in the IT revolution. Logically citizens will be getting divided into people who do and people who don't have access to ICT and the capability to use modern information technology. This divide exists and shall remain to exist between the cities and rural areas, between the rich and the poor, and between the educated and uneducated (Alam, 2010).

8. Third Generation: 3-G Technology is recently entered into our country. Those people who are not able to fulfill their fundamental rights, they will be the extreme victim of digital divide.

\section{FINDINGS OF THE STUDY}

1) Generation gap is one of the effects of digital divide.

2) The problem of e-service delivery system of egovernment is increasing digital gap between the poor and rich, young and old, senior and junior, rural and urban etc.

3) Usability and empowerment divide is the direct cause of digital divide and this type of divide is occurring only for mismanagement of e-government.

4) Lack of responsibility and accountability of govt. is one of the major barriers of e-government and this problem is creating digital divide.

5) Poverty is another cause of digital divide.

\section{Conclusion and ReCommendations}

Of course e-governance is blessing and inevitable for the current internet base technology and development. We are benefited and developed by e-governance. But due to this process it brings a gap between developed and underdeveloped countries, between urban and local areas. E-governance is ICT based system and digital divide is creating for unequal access and use of ICT. Digital divide has attracted much attention as a possible cause of economic disparities in the new economy, but it is more probable that the digital divide is itself an effect of disparities that have long existed. Any serious solution to poverty will have to reach beneath the digital divide and confront the underlying gap between rich and poor. To bridge the gap computer based training and education must need. It is evident that e-governance is intrinsically linked with the development of computer technology, networking of computers and communication systems. Through time digital gap and divide is seen every generation, society and country. But it is accepted when its degree and level become tolerable. If government and other agencies are concerned to the success of egovernance, then the total process will get a golden structure. Proper application and implementation of policy, honesty and patriotism is needed to minimize the digital divide. Government and other agencies should work according to ethics.

\section{REFERENCES}

[1] Bhatnagar, S. E-Government: From vision to Implementation; Sage publications, 2004.

[2] Devraj, R. South Asia: Digital divide sharpens Richpoor Gap, (2006).

[3] DiMaggio, p. and E. Hargittai.(2001)."From the 'Digital Divide to 'Digital Inequality': Studying Internet Use as Penetration Increases." Princeton: Centre for Arts and Cultural Policy Studies, Woodrow Wilson School, Princeton University.

[4] DiMaggio, p. and Hargittai, E.,Celeste, C., and Shafer, S.(2004).Digital Inequality: From Unequal Access to Differentiated Use. In Social inequality, ed. K Neckerman, pp. 355-400. New York: Russell Sage Foundation. 
[5] Ghosh, A. \& Arora, N. Role of e-governance:Frameworks in effective implementation, ICEG, Lahore, Pakistan. 2005.

[6] Inaugural address at IIT Delhi during International Conference on E-Governance.

[7] Kumar, V., (2000), International Marketing Research, Harvard Business Review, Vol. XXXIV, No. 2, PP. 40-60.

[8] Rahman, M.H. \& Naz, R. (2006); Digital divide within society; an account of poverty, community and egovernance in Fiji. Volume 3, Number 3.

[9] Report of the Working Group on convergence and Egovernance for the Tenth Year Plan (2002-2007), Planning Commission, November, 2001.

[10] Riley, B.T. E-governance vs. E-government, NovemberDecember, 2003.

[11] Roxana Barrantes Caceres, Digital poverty: concept and measurement with an application to Peru, Working paper \# 337-March 2007.

[12] Singh, S.H. Ways and means of bridging the gap between developed and developing countries, High-level panel on IT and public administration, United States, 2000.

[13] Venkat, K. Digital divide and poverty, The Howorth Press, 2001.

[14] Warschauer,M. (2003). Technology and Social Inclusion: Rethinging The Digital Divide. Cambridge, MA: MIT Press.

[15] Warschauer,M. (2003). Demystifying the Digital Divide. Scientific American, Vol.289 (Issue 2), S.42.

[16] Wilson, K. R. Wallin, J.S. \& Reiser C.(2003). Social Stratification and the Digital Divide, Social Science Computer Review, Vol.21 No. 2, 133-143.

\section{Internet references}

[17] E-government Act of 2002; (from http:/ / frwebgate.access.gpo.gov/cgibin/getdoc.cgi?db name=107-cong-public laws7docid=f: pub1347.107.pdf).

[18] http://www.ejisdc.org, The Electronic Journal on Information System in Developing Countries.

[19] ALADI. (2003). La Brecha Digital y sus Repercusiones en los Países Miembros de la ALADI [The DigitalDivide and Its Impact on ALADI Member Countries], Asociación Latinoamericana de Integración [Latin American Association for Integration] -
ALADI, $194 \quad$ pp. $\quad$ Retrieved from http:/ / www.aladi.org/nsfaladi/titulare.nsf/5c424a97a 14f01e0032568e00046db1b/fa8db613acb8 beee03256d74004dcd3a/\$FILE/157Rev1.doc.

[20] World Bank. (2002). Information and Communication Technologies: A World Bank Group Strategy. Retrieved May 3, 2005, from http://info.worldbank.org/ict/assets/docs/sp_ExecSum.pdf

[21] World Bank. (2003). ICT and MDGs: A World Bank Group perspective, World Bank Group's Global ICT Department. Washington D.C. 39 pp. Retrieved April 30, 2005, from http://info.worldbank.org/ict/assets/docs/mdg_Com plete.pdf

[22] ETS. (2002). Digital Transformation. A Framework for ICT Literacy. A report of the International ICT literacy panel. Retrieved May 16, 2005, from

[23] http://www.ets.org/research/ictliteracy/ictreport.pdf

[24] INEI. (2003). Encuesta Nacional De Hogares sobre Condiciones de Vida y Pobreza [National Household Survey on Living Standards and Poverty] - ENAHO 2003, Instituto Nacional de Estadística e Informática [National Institute of Statistics and Computer Science] INEI, Data Base.

[25] Nyaki, C. (2002). ICT and Poverty: A Literature Review, International Development Research Center- IDCR, 58 pp. Retrieved May 27, 2005, from http:/ / network.idrc.ca/uploads/userS/10541291550ICTPovertyBiblio.doc.

[26] http://network.idrc.ca/ev.php?URL_ID=24718\&URL_D $\mathrm{O}=$ DO_TOPIC\&URL_SECTIONORBICOM. (2003). Monitoring the Digital Divide... and Beyond. Orbicom, Canadian Agency for International Development, InfoDev and UNESCO, 161 pp. Retrieved May 10, 2005, from http://www.infodev.org/files/836_file_The_Digital_D ivide.pdf.

[27] ITU. (2003). New Digital Access Index. International Telecommunications Union, ITU. p. 6-17. Retrieved May 29, 2005, from http://www.itu.int/ITU D/ict/dai/material/DAI_ITUNews_s.pdf. 